\title{
Isolation, Identification and Molecular Characterization by RAPD of Red HE7B Dye Decolourizing Bacteria from Textile Effluents and its Cultivated Soil
}

\author{
A.D. Patel ${ }^{*}$, H.P. Gajera, S.V. Patel and B.A. Golakiya \\ Food Testing Laboratory (NABL accredited), Department of Biotechnology \\ Junagadh Agricultural University, Junagadh-362001, Gujarat, India \\ *Corresponding author
}

\begin{abstract}
A B S T R A C T
Colours give delightful pleasure to eyesight but at the same time they may act as serious pollutants when their origin is dyes and dyestuffs. The textile industry is one of the industries that generate a high volume of waste water. Strong colour of the textile waste water is the most serious problem of the textile waste effluent. Total 26 bacterial isolates were isolated from fourteen different effluents and its contaminated and cultivated soil.

Keywords

Textile effluents, Red HE7B dye, RAPD,

Pseudomonas, Molecular marker.

Article Info

Accepted:

14 September 2017 Available Online: 10 October 2017

Dye decolourization study was carried out using all 26 isolates with one dye (Red HE7B $100 \mathrm{ppm}$ ) for checking potentiality of isolated bacterial isolates. After 10 days of incubation with bacterial isolates, 14 isolates gave satisfactorily decolourization above $70 \%$ compared with control. The morphological, microscopic and biochemical characterization of selected 14 bacterial isolates (Ps1 to Ps14) was carried out. All 14 bacterial isolates were found either circular or round in shape except Pseu-ghat-eff-4 which is found irregular in shape. All 14 bacterial isolates identified as Pseudomonas sp. The genomic DNA was isolated from 24 h old Pseudomonas bacterial cultures. The RAPD was performed using genomic DNA of 14 Pseudomonas sp. to generate diversified map and identification of specific markers associated with decolourization activity. Total 172 fragments were generated by 17 RAPD primers across 14 bacterial isolates. Out of 170 bands, 122 bands were shared polymorphic which was found at least more than two isolates and 48 bands were unique polymorphic bands. Jaccard similarity coefficient was found in the range of 0.137 to 0.368 in clustering pattern of 14 bacterial isolates. Best bacterial isolates, Ps4 with respect to dye decolourization was distinguished by 6 unique bands amplified by OPA-07 (356bp), OPA-18 (577), OPB-18 (1150), OPD-02 (2152), OPF-15 (1079) and OPZ-15 (2694bp) makers. However, Ps10 was distinguished by 4 unique bands amplified by OPF-06(1817bp), OPF-15(1535bp), OPO-06(2208bp) and OPO-13(484bp).
\end{abstract}

\section{Introduction}

The textile industry is one of the industries that generate a high volume of waste water. Strong colour of the textile waste water is the most serious problem of the textile waste effluent. The disposal of these wastes into receiving water causes damage to the environment. With regard to their colour removal by conventional treatment methods lead to severe water pollution, thus developing cost effective clean-up operations (Willmott et al., 1998). Microbial degradation seems to be promising compared to other 
organisms and the method of application are simpler compared to other available methods. Several combined anaerobic and aerobic microbial treatments had been suggested to enhance the degradation of textile dyes (Haug et al., 1991). Several methods are used in the treatment of textile effluents to achieve decolourization. These include physiochemical methods such as filtration, specific coagulation, use of activated carbon and chemical flocculation. Some of these methods are effective but quite expensive (Maier et al., 2004). Biological treatment offers a cheaper and environmentally friendlier alternative for colour removal in textile effluents. Microbial decolourization of dyes is a cost effective method for removing them from waste waters. Hence, present experiment formulated to study bacterial decolourization of Red HE7B dye with identification and molecular characterization by RAPD.

\section{Materials and Methods}

\section{Dyes and chemicals}

Commercially graded reactive Azo dye Red HE7B used in present study was procured by local dealer. All the chemicals and fine biochemical used in the experiments were of either analytical grade or molecular grade from standard manufacturers like SigmaAldrich, Himedia, Qualigenes, Rankem, SISCO etc.

Soil and effluent sample were collected from different location of nearby area of textile industries in Jetpur, Gujarat, India for isolation of dye degrading bacteria.

\section{Isolation of bacterial strain}

The dye decolourizing bacteria were isolated by using enrichment culture technique (Safia et al., 2005). Bacteria were isolated in BHM media amended with Red HE7B dye at $100 \mathrm{ppm}$ along with glucose and yeast extract as co-substrate. Dye-containing media (100 $\mathrm{ml}$ )in $250 \mathrm{ml}$ Erlenmeyer flasks were inoculated with $10 \mathrm{ml}$ of effluent and soil suspension (10\% w/v) and incubated under static conditions at $37^{\circ} \mathrm{C}$.Consortia which showed decolourization in liquid media were tested further by transferring in fresh dye containing media for consistent decolourization in every successive transfer. The isolated bacteria were subjected to serial dilution $\left(10^{-5}\right)$ and spread on citrimade agar plate for pure colony isolation of the bacteria. The various colonies obtained on plate were transferred individual in to $\mathrm{N}$-agar media. As a result, total 26 bacteria isolates differ in colony characteristics were obtained and it was used for preliminary screen test against Red HE7B dye (100ppm). The representative types of colonies were further transferred on $\mathrm{N}$-agar medium and pure isolates were preserved on $\mathrm{N}$-agar slant and stored at low temperature in refrigerator.

\section{Identification of microbes}

The bacterial isolates were identified on the basis of their different morphological characters likesize, shape, margin, elevation, texture, opacity, pigmentation. They also identified on the basis of microscopic examination by gram's staining and different biochemical tests.

\section{Dye decolourization experiment of red HE7B dye}

The suspension of $24 \mathrm{~h}$ old cultures of all bacterial isolates was used to investigate their abilities to decolourized dyes. Solution was prepared in $0.85 \% \mathrm{NaCl}$ saline solution Dye decolourizing experiment were carried out in $100 \mathrm{ml}$ sugar tube containing $50 \mathrm{ml}$ of direct azo dye (100ppm) and traces of yeast extract, and glucose. The stock solution (1 Liter) was 
prepared using Bussnall and Huss Medium (BHM).

The 50ml solution from stock $(\mathrm{pH} 7 \pm 0.2)$ was poured into tubes, plugged with nonabsorbent cotton and autoclaved at $121^{\circ} \mathrm{C}$ for 15 minutes. The autoclaved tubes were inoculated with $10^{6} \mathrm{CFU}$ of bacterial inoculums of each isolates. The tubes were kept in static condition at room temperature for 10 days. Samples were drawn at 2 days intervals for observations or each observation $2 \mathrm{ml}$ of the dye solution was filtered and centrifuge at $10000 \mathrm{rpm}$ for 10 minutes and subjected to decolourization assay. Decolourization assay (Kalme et al., 2007)

Decolourization assay was measured in the terms of percentage decolourization using UV spectrophotometer. The percentage decolourization was calculated from the following equation,

$\%$ Decolourization $=$ (Initial OD-Final OD)*100/Initial OD

The average decolourization rate $\mu \mathrm{g} \cdot \mathrm{h}^{-1}$ was calculated from the following equation

$(\mathrm{C} * \% \mathrm{D} * 1000 /(100 * \mathrm{t})$

Where $\mathrm{C}$ is the initial concentration of dye (mg. $\mathrm{l}^{-1}$ ) and $\% \mathrm{D}$ is the dye decolourization (\%) after time $\mathrm{t}(\mathrm{h})$.

\section{RAPD analysis}

Molecular characterization through DNA marker (RAPD) was carried out following the method (David et al., 2007) with minor modifications. RAPD- PCR amplification was carried out. Seventeen decamers (A2,A7,A18,B18,C9,D2,D3,D7,F6,F15,H15,J 7,K3,O6,O13,O15,Z15;operaon technology) were used to recover genetic diversity among the isolated bacterial strain. RAPD amplification was carried out in $20 \mu \mathrm{l}$ of reaction mixtures containing: $2.0 \mu \mathrm{l}$ of cell DNA plus $18 \mu \mathrm{l}$ reaction mixture (10X Taq Buffer 2.0 $\mu 1,1 \mathrm{U} / \mu \mathrm{l}$ Taq polymerase 0.5 $\mu 1,10 \mathrm{mM} / \mu 1 \mathrm{dNTP} \operatorname{mix} 2.0 \mu \mathrm{l}$, Primer $2.0 \mu \mathrm{l}$,

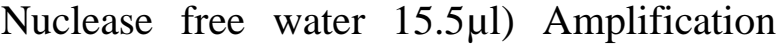
conditions were as follows: two cycles, each consisting of $30 \mathrm{~s}$ at $94{ }^{\circ} \mathrm{C}, 30 \mathrm{~s}$ at $36{ }^{\circ} \mathrm{C}$ and 2 min at $72{ }^{\circ} \mathrm{C} ; 20$ cycles, each consisting of $20 \mathrm{~s}$ at $94{ }^{\circ} \mathrm{C}, 15 \mathrm{~s}$ at $36^{\circ} \mathrm{C}, 15 \mathrm{~s}$ at $45^{\circ} \mathrm{C}$ and 2 min at $72{ }^{\circ} \mathrm{C}$; 18 cycles, each consisting of $20 \mathrm{~s}$ at $94{ }^{\circ} \mathrm{C}$ (after each cycle $1 \mathrm{~s}$ more), $15 \mathrm{~s}$ at $36{ }^{\circ} \mathrm{C}, 15 \mathrm{~s}$ at $45{ }^{\circ} \mathrm{C}$ and $2 \mathrm{~min}$ at $72{ }^{\circ} \mathrm{C}$ (after each cycle $3 \mathrm{~s}$ more). After the 40th cycle, a final extension step of $10 \mathrm{~min}$ at 72 ${ }^{\circ} \mathrm{C}$ was performed. Polymorphic information content (PIC) for RAPD was calculated on the basis of allele frequency.

\section{Results and Discussion}

\section{Screening of Isolated Bacteria}

Total 26 bacterial isolates were isolated from fourteen different effluents and soil sample. Dye decolourization study was carried out using all 26 isolates with one dye (Red HE7B $100 \mathrm{pp}$ ) for checking potentiality of isolated bacterial isolates. After 10 days of incubation with bacterial isolates 14 isolates gave satisfactorily decolourization above $70 \%$ compared with control as described in (Graph 1). These 14 isolates were selected for further study.

\section{Identification of isolated bacteria}

\section{Morphological characteristics}

The 14 bacterial isolates were examined for their colony characteristics.

The shape of bacterial colony were found either circular or round except Pseu-ghat-eff4.The bacteria were found in sticky texture except Ps 5 and 9. Tranluscent opacity and 
convex elevation were recorded in bacterial colony. Some bacteria produced pigment when grown in $\mathrm{N}$-agar culture.

\section{Identification based on microscopic and biochemical test}

The Gram's staining of isolated bacterial sp. showed that all 14 isolates were short rod shaped, stained red in colour and identified as gram negative. All 14 isolates were tested for their biochemical characters viz., oxidase test, glucose fermentation test, Motility test, starch hydrolysis, casein hydrolysis, $\mathrm{H}_{2} \mathrm{~S}$ production, Indole production, and catalase test.

The biochemical characterization of all bacterial isolates showed same results found by Cappuccino et al., (1992). All isolates were showed oxidase test positive. However glucose fermentation test was found to be as negative no colour change from red to yellow in tube. All isolates were showed positive for catalase test, but negative for starch hydrolysis and motility test. Isolates Ps 1, 3,
$4,7,8,10,11$, and 14 were showed positive result for $\mathrm{H}_{2} \mathrm{~S}$ on SIM agar tube. The same strains also were showed positive result for Indole by colour change in SIM agar tube. Isolates Ps 1, 4, 7, 10, 11, 12 and 14 were showed positive result for Casein hydrolysis by giving clear zone on Skim milk agar plate. All isolates showed growth at $41^{\circ} \mathrm{C}$ however 5 isolates were able to grow at $4^{\circ} \mathrm{C}$. According to Bergey's manual chart the isolates were identified as Pseudomonas sp.

\section{Decolourization of red HE7B dye}

Dye decolourization of Red HE7B was found to be significant when incubated with bacterial isolates. The highest decolourization was observed with Ps-10 (78.30\%) followed by Ps- 1 (71.58\%), Ps-12 (68.49\%) and Ps-4 $(68.45 \%)$. The lowest mean decolourization was found when dye was incubated with Ps-2 (28.83\%). Irrespective of Pseudomonas strain, dye decolourization significantly increased with increasing incubation period up to 10 days (Fig. 1).

Graph.1\% dye decolouization after 10 Days of Inoculation

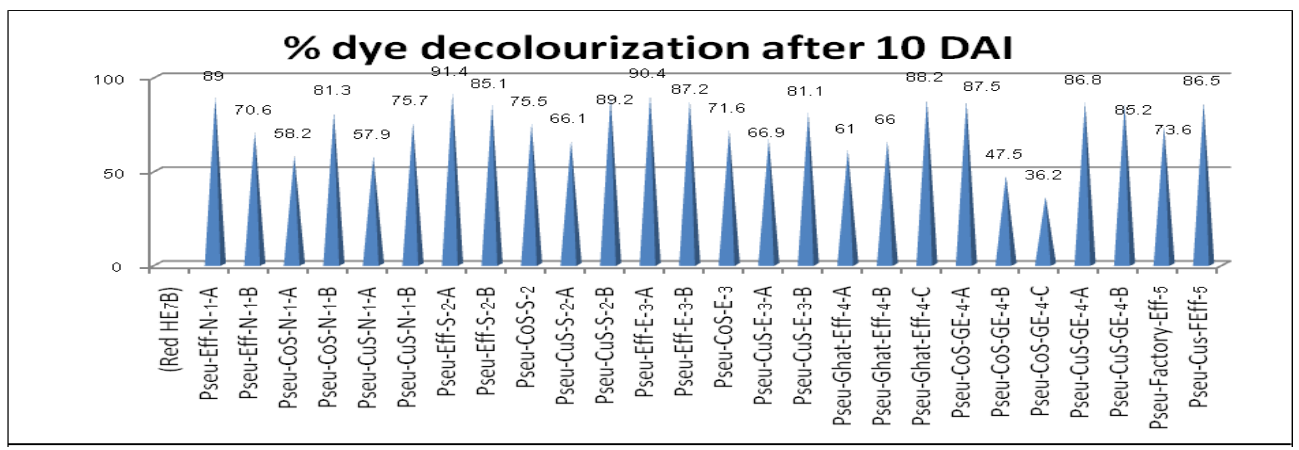

Graph.2 \% Decolourization of Red HE7B dye)

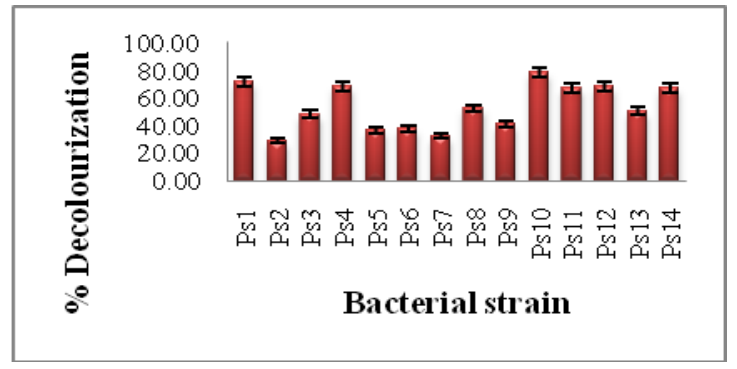


Fig.1 \% dye decolourization of Red HE7B by Ps4 isolate

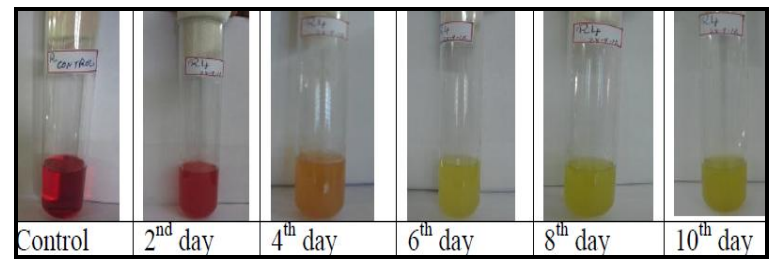

Fig.2 RAPD profile of 14 bacterial strain using primer
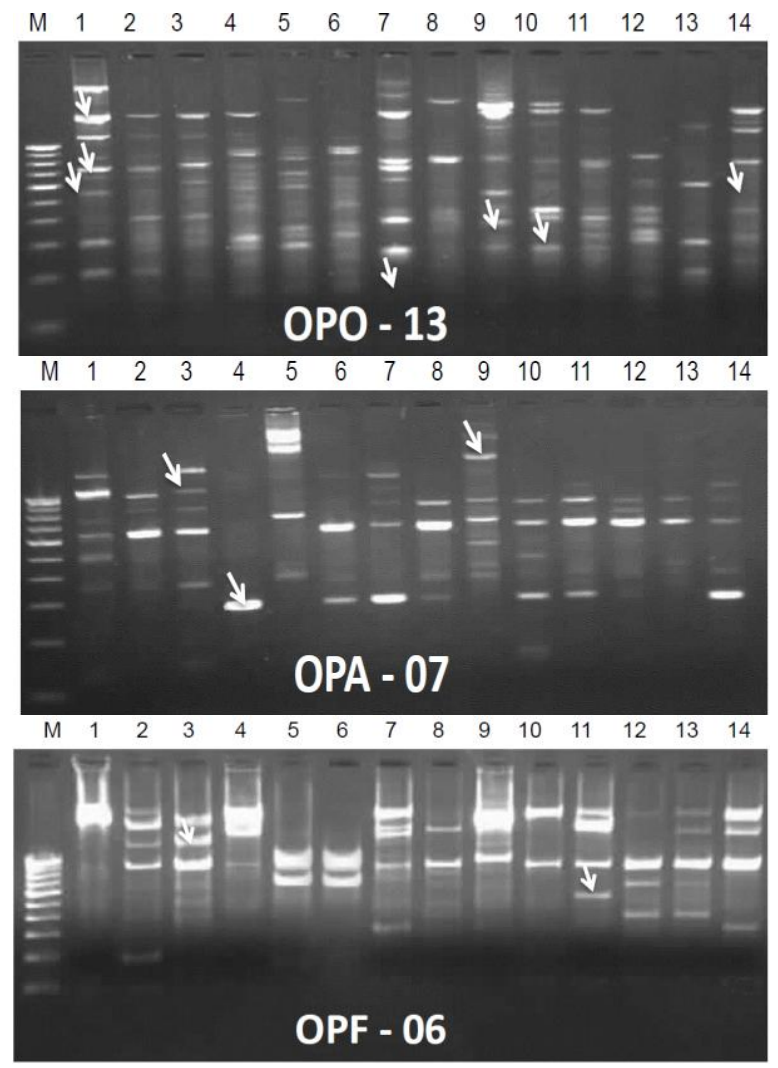

Fig.3 Dendrogram depicting the genetic relationship among isolated bacterial isolates based on the RAPD data

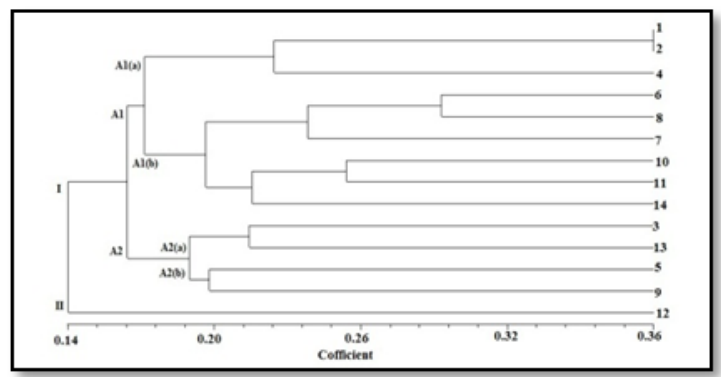

(1= Pseu-Eff-N-1; $2=$ Pseu-CoS-N-1; $3=$ Pseu-CuS-N-1; 4= Pseu-Eff-S- $2 ; 5=$ Pseu-CoS-S-2; 6= Pseu-CuS-S- $2 ; 7=$ Pseu-Eff-E-3; 8= Pseu-CoS-E-3; 9= Pseu-CuS-E-3; 10= Pseu-Ghat-Eff-4; 11= Pseu-CoS-GE-4; $12=$ Pseu-CuS-GE4; 13= Pseu-Factory-Eff-5; 14= Pseu-Cus-FEff-5) 
The maximum decolourization was obtained with D2 to D4 incubation. Interaction effect of Pseudomonas strain with different incubation period for $\%$ dye decolourization of Red HE7B showed significant difference. The major dye decolourization was obtained when Ps10 (90.20\%) strain incubated with Red HE7B dye and kept for 10 days, followed by Ps12 (88.65\%), Ps1 (87.64\%) and Ps4 $(85.82 \%)$. Overall, dye decolourization was increased with increasing incubation period.

\section{RAPD analysis}

The polymorphisms can be detected by the use of Random Amplified Polymorphic DNA (RAPD) which does not require prior knowledge of the genome. These random primers were obtained from Bangalore Genei, India. The amplified products generated using a common PCR protocol for all primers were separated on a $1.5 \%$ agarose gel matrix (Fig. 2). The RAPD profiles visualized presence of high level of polymorphism between the isolated bacterial isolates. The highest numbers of 17 bands were produced by OPO13 primer followed by 14 bands of OPA-07. The largest fragment of 324-3204 bp was amplified by OPF-06. Total 172 fragments were generated by 17 RAPD primers across 14 bacterial isolates. Out of 172 bands, 170 bands were polymorphic. The average polymorphism obtained was $98.04 \%$.Out of 170 bands, 122 bands were shared polymorphic bands which were found in at least more than two isolates and 48 bands were unique polymorphic bands. Best bacterial isolates, Ps4 with respect to dye decolourization was distinguished by 6 unique bands amplified by OPA-07 (356bp), OPA-18 (577), OPB-18 (1150), OPD-02 (2152), OPF15 (1079) and OPZ-15 (2694bp) makers. However, Ps10 was distinguished by 4 unique bands amplified by OPF-06(1817bp), OPF15(1535bp), OPO-06(2208bp) and OPO13(484bp).
The bacterial isolates were grouped into two main clusters: cluster I and cluster II and shared $14 \%$ similarity. Cluster II contain single bacterial strain 12, while cluster I was divided in to two sub clusters cluster $\mathrm{A} 1$ and A2. Cluster A1 and cluster A2 comprised of 13 bacterial isolates and shared $16 \%$ similarity. Cluster A1 was further divided in to two cluster A1 (a) and A1 (b). The A1 (a) cluster consisted of three bacterial isolates with having $39 \%$ similarity. Among the three strains (1, 2, and 3), 1 and 2 are similar, and strain 4 is similar with 1 and 2. Cluster A1 (b) consisted of Ps 6, 7, 8, 10, 11 and 14 having $20 \%$ similarity. Cluster A2 was also further divided in to two clusters: cluster A2 (a) and cluster A2 (b). Cluster A2 (a) consisted of Ps3 and 13 having $22 \%$ similarity. Cluster A2 (b) consisted of strain 5 and 9 (Fig. 3).

Among the 14 isolated bacteria Ps10 showed highest dye decolourization rate in Red HE7B azo dye. The maximum decolourization rate was obtained by the best the strain Ps10 (78.30\%) for Red HE7B dye. The molecular characterization of bacterial isolates produced some markers which discriminate best Pseudomonas sp. which degrade Red HE7B.This bacterial consortium can be used to treat the waste water and after treatment these water can be used for the irrigation. The molecular characterization of effective Pseudomonas strain help in identification and diversity analysis among bacterial isolates.

\section{References}

Cappuccino, J. G., and Sherman N., 1992.Microbiology a laboratory manual. The Benjamin Cummings Publishing Company Inc., California.

David, G., Fabio, R. and Cesaro G. 2007. Quantification of the biocontrol agent Pseudomonas fluorescens Pf153 in soil using a quantitative competitive PCR aasay unaffected by variability in cell 
lysis and DNA extraction efficiency. Soil Biology and Biochemistry., 16091619.

Haug, W. A., Schmidt, B., Nortemann, D. C., Hempel, A., Stolz and Knackmuss, H. J. 1991. Mineralization of sulphonated azo dye mordant yellow 3 by a 6aminoaphthalene-2-sulfonate-degrading bacterial consortium. Applied Environ. Microbial, 57: 3144-3149.

Kalme, S., Ghodake, G. and Govindwar, S. 2007. Red HE7B degradation using desulfonation by Pseudomonas desmolyticum NCIM 2112. Int. Biodet Biodeg, 60: 327-333.
Maier, J., Kandelbauer, A., Erlacher, A., Cavaco, A., and Gubits, G. M. 2004.A new alkali - thermo stable azoreductase from bacillus sp. Strain SF. Appl. Environ. Microbiol., 70: 837 - 844.

Safia, M., Haresh, K. and Datta, M. 2005. Decolourization of textile dye reactive violet 5 by a newly isolated bacterial consortium RVM 11.1. World J. Microbiol. Biotechnol., 21: 667-672.

Willomott, N. J., and Nelson, G. 1998.The biotechnological approach to colour removal from textile effluent. J. Soc. Dyrescolourist., 114: 38-41.

\section{How to cite this article:}

Patel, A.D., H.P. Gajera, S.V. Patel and Golakiya, B.A. 2017. Isolation, Identification and Molecular Characterization by RAPD of Red HE7B Dye Decolourizing Bacteria from Textile Effluents and Its Cultivated Soil. Int.J.Curr.Microbiol.App.Sci. 6(10): 1478-1484. doi: https://doi.org/10.20546/ijcmas.2017.610.175 